\title{
Strategic circumvention of regulations: the judicialization of the Brazilian private health system
}

\author{
ARNALDO L. RYNGELBLUM ${ }^{1}$ \\ Paulo C. Duarte de Oliveira ${ }^{2}$ \\ Renato Telles ${ }^{1}$ \\ MAYLA C. $\operatorname{COSTA}^{3}$ \\ 1 Universidade Paulista (Unip) / Programa de Pós-Graduação em Administração, SÃo Paulo - SP, Brazil \\ ${ }^{2}$ UnIVERSIDAde PAULISTA (UNIP) / FACULdAdE DE AdMINISTRAÇÃO, SÃO PAULO - SP, BRAZIL \\ 3 Universidade Federal do Paraná (UFPR) / Programa de Contabilidade, Curitiba - PR, BRAZIL
}

\begin{abstract}
The article aims to advance the understanding of the successive circumvention of regulations by organizations, to determine whether it is possible to characterize them as purposeful actions, while the institutional literature analyzes decoupling and circumvention as sporadic activities. It analyzes the responses adopted by health plan companies to favor their interests, responses that often fail to comply with the rules of the institutional context, and which boosted the phenomenon known as 'judicialization'. The study analyzed 158 lawsuits collected from the electronic archives of the Court of Justice of São Paulo, where beneficiaries sue health plan companies because of treatment coverage denial. Using correspondence and thematic analysis, some associations between denials and allegations showed to be significant, suggesting companies' strategic patterns. It was possible to identify different strategic practices adopted by companies to avoid complying with institutional guidelines, and to observe that certain regulatory features can contribute to non-compliance strategies. The article contributes to the institutional literature by identifying organizational practices meant to successively circumvent and confront institutional prescriptions, indicating that health plan companies apparently design specific strategies to respond to beneficiaries' demands.
\end{abstract}

Keywords: Institutional theory. Health care. Regulation. Justice. Strategy.

\section{Evasão estratégica das regulações: a judicialização do sistema privado de saúde brasileiro Resumo}

O artigo busca aprofundar a compreensão sobre as evasões sucessivas às regulações pelas organizações, de modo a estabelecer se é possível caracterizá-las como ações intencionais, enquanto a literatura institucional analisa o descolamento e a evasão como atividades esporádicas. Nesse sentido, o artigo analisa as respostas adotadas pelas companhias de planos de saúde para favorecer seus interesses, que frequentemente deixam de cumprir as regras do contexto institucional, e que acabou por provocar o fenômeno da 'judicialização'. Os dados analisados foram levantados nos arquivos eletrônicos do Tribunal de Justiça de São Paulo e a análise é o resultado de 158 ações impetradas por beneficiários contra os planos de saúde devido a negativas de cobertura de tratamentos. Ao fazer uso de análise de correspondência e análise temática, algumas associações entre negativas e alegações mostraram-se significativas, sugerindo padrões estratégicos das operadoras. 0 trabalho identificou diferentes práticas estratégicas adotadas para evitar cumprir com diretrizes institucionais e argumenta que determinadas características regulatórias podem contribuir para as estratégias de descumprimento. A contribuição para a literatura institucional reside na identificação de práticas organizacionais voltadas para sucessivamente evadir e confrontar as prescrições institucionais, indicando que as operadoras de planos de saúde aparentemente elaboram estratégias específicas para responder às demandas dos beneficiários.

Palavras-chave: Teoria Institucional. Saúde. Regulação. Justiça. Estratégia.

\section{La evasión estratégica de las regulaciones: la judicialización del sistema de salud privado brasileño}

\section{Resumen}

El artículo tiene como objetivo avanzar en la comprensión de la evasión sucesiva de las regulaciones por parte de las organizaciones, para determinar si es posible caracterizarlas como acciones intencionales, mientras que la literatura institucional analiza el desacoplamiento y la evasión como actividades esporádicas. De esta forma, analiza las respuestas adoptadas por las compañías privadas de seguros de salud para favorecer sus intereses que a menudo no cumplen con las reglas del contexto institucional y que impulsaron el fenómeno conocido como 'judicialización'. Los datos analizados se recopilaron en los archivos electrónicos del Tribunal de Justicia de São Paulo y el análisis es el resultado de 158 demandas presentadas por beneficiarios individuales contra los operadores del seguro de salud debido a la negativa de cobertura de tratamientos. Usando la correspondencia y el análisis temático, algunas asociaciones entre las negaciones y las alegaciones se mostraron significativas, lo que sugiere patrones estratégicos de los operadores. El trabajo identificó diferentes prácticas estratégicas que los operadores adoptan para evitar cumplir las directrices institucionales, y argumenta que ciertas características regulatorias pueden contribuir a las estrategias de incumplimiento. La contribución a la literatura institucional reside en la identificación de prácticas organizacionales destinadas a evadir y enfrentar sucesivamente las prescripciones institucionales, lo que indica que los operadores de seguros de salud aparentemente diseñan estrategias específicas para responder a las demandas de los beneficiarios.

Palabras clave: Teoría institucional. Salud. Regulación. Justicia. Estrategia. 


\section{INTRODUCTION}

The institutional theory in sociology considers that organizations may feel unable to comply or may not completely agree, at specific moments, with the prescriptions imposed by the practices and rules prevalent in an institutional context (SCOTT, 2008; SMETS, MORRIS and GREENWOOD, 2012; BLACK, 2017). According to the theory, the organizations will then resort to strategic practices that allow them to evade such prescriptions (OLIVER, 1991; MEYER and ROWAN, 1991; SUCHMAN, 1995; DURAND and KREMP, 2016).

Studies understanding that a dominant or hybrid logic prevails in an institutional context (LEBLEBICI, SALANCIK, COPAY et al., 1991; RAO, MONIN and DURAND, 2003; BATTILANA and DORADO, 2010; TRACEY, PHILLIPS and JARVIS, 2011), consider organizations decoupling and circumvention as sporadic activities carried out to evade unwanted practices at specific moments. Other research that considers organizational contexts constituted by multiple logics, show that actors may have to circumvent various logics at certain moments, due to the determinations of the prevailing logic (RUEF and SCOTT, 1998; GOODRICK and REAY, 2011; THORNTON, OCASIO and LOUNSBURY, 2015). However, even in situations where actors may need to undertake different activities to evade logics they cannot comply with, these practices may be different every time they perform them.

Some authors have brought attention to actors and to the processes by which these actors make change happen (HARDY and MAGUIRE, 2008; BATTILANA, LECA and BOXENBAUM, 2009), sharing an assumption that institutional change is an outcome of purposeful "institutional work" (LAWRENCE, SUDDABY and LECA, 2009, 2011; MICELOTTA, LOUNSBURY and GREENWOOOD, 2017). These studies downplay how social structures can enable and provide multiple pathways for action (SCHNEIBERG and LOUNSBURY, 2008; FLIGSTEIN and MCADAM, 2012; THORNTON, PHILLIPS and JARVIS, 2012; MICELOTTA, LOUNSBURY and GREENWOOOD, 2017).

This article examines the successive circumvention of regulations observed in the practice of health plan companies, which have not been significantly explored in literature. Instead of studying the circumvention of different institutional logics, the aim is to explore, based on the institutional logic perspective, how the successive circumvention of the same regulation occurs and if this repeated circumvention constitutes an intentional strategy in this organizational field in Brazil.

Since treatment coverage denial is one of the various reasons for the judicialization phenomenon, this article analyzes the practices health plan companies adopt in the field of supplementary health to circumvent complying with agreed rules and procedures, as defined by the sector's regulator. The literature review points to the relevance of the topic since studies show occasional circumvention of institutional prescriptions. Furthermore, the results can contribute to analyze the relationship between regulation and judicialization growth, arguing that regulatory apparatus in developing countries may be responsible for companies' nonconformity strategies.

\section{LITERATURE REVIEW}

The institutional logics perspective presupposes the interrelationship between institutions, organizations and individuals in social systems, based on the consideration that society is composed of multiple rationalities (FRIEDLAND and ALFORD, 1991; THORNTON, OCASIO and LOUNSBURY, 2012, 2015). These logics are responsible for influencing the social actors' frame of reference and even their self-interest, by "[...] integrating the symbolic with the material, the institutional logics perspective integrates research on culture and cognition to provide an orienting strategy for a theory of how culture shapes action" (THORNTON, OCASIO and LOUNSBURY, 2012, p. 11).

Greenwood, Raynard, Kodeih et al. $(2011$, p. 1) consider that "[...] organizations face institutional complexity whenever they confront incompatible prescriptions from multiple institutional logics". According to Pache and Santos (2010), the strategy adopted by an organization will be partly a function of the fact that multiple logics are directly represented within an organization. Organizational responses are the result of the competition between logics, which causes the prioritization of logics to be determined by the relative power of each logic's representative, how it has been given voice and the capacity to have it heard (GREENWOOD, RAYNARD, KODEIH et al., 2011). Considering that logics are comprised by practices and rules, strategic actions can be considered as one of these practices (THORNTON, OCASIO and LOUNSBURY, 2012; LEE and LOUNSBURY, 2015; GREVE and MAN ZHANG, 2017). In this case, the organizational response corresponds to an 
institutional strategy (in contrast with a competitive strategy) determined by an actor that has power in a specific event to promote a logic.

Albuquerque and Machado da Silva (2009, p. 632) argue that organizational practices are "[...] regular and recurrent social actions that continually build and rebuild the organization as a spatially and temporally delimited social system". Thornton, Ocasio and Lounsbury (2012) consider that practices are sets of activities that have social significance, and therefore, involve a coherent meaning and stability in a certain context.

New logics are usually adapted or created from practices, structures or forms, understandings, and symbols that exist a priori, by accessing the elements of pre-existing logics (BERGER and LUCKMANN, 1991; NEE, 1998). In this sense, institutional arrangements refer to sociocultural constructs that prescribe organizational behaviors that are considered appropriate, but are in a historically constant process to "[...] shape and enforce patterns of interests and privilege" (DACIN, GOODSTEIN and SCOTT, 2002, p. 45).

For these theorists, many of the institutional forms and practices used by modern organizations are not necessarily adopted because they are more effective, but because they reinforce their social legitimacy and the legitimacy of their members (SCOTT, 2008). Organizations may decouple from these prescriptions by adopting other more effective ones in parallel (MEYER and ROWAN, 1991).

However, it is possible to question the understanding that organizations decouple from these instituted practices in favor of more effective or efficient ones (BOXENBAUM and JONSSON, 2008). For example, when a company postpones a debt repayment for a long period of time, claiming that its value is incorrect or another justification, it risks damaging its reputation or the debt is suspended until the allegation is verified. During this process, the company can improve its cash flow management improvement based on the fact that it delayed payments. This means that the practice of circumventing the payment in due time is meant to improve the company's performance.

The studies that examined the situation when one logic becomes dominant, consider that this logic will guide and constrain organizational decisions and behaviors (LEBLEBIC, SALANCIK, COPAY et al., 1991; RAO, MONIN and DURAND, 2003). This is also seen for situations when competing logics combine to generate a hybrid logic to orient an institutional context (BATTILANA and DORADO, 2010; TRACEY, PHILLIPS and JARVIS, 2011). These studies handle circumvention of institutional prescriptions as a sporadic situation that actors resort to because they don't agree (completely or in part) with the prescriptions, or because they have another understanding of the logic.

In contrast, when the analysis understands that multiple logics are represented, the definition about which logic will prevail at specific moments, will depend on the distribution of power in that context (RUEF and SCOTT, 1998; REAY and HININGS, 2009; GOODRICK and REAY, 2011). In this case, the attendance to one of the logics makes it necessary to decouple or circumvent in relation to the other logics in the context. The organization will develop the necessary practices in this regard. This type of analysis means the actors have to circumvent different logics to attend one that has prevailed. Again, it is possible to notice that these studies refer to circumvention practices that are related to different objectives.

This article intends to explore the successive circumvention of one logic proposing that actors follow the rules inside the context under analysis. The analysis assumes that, since the circumvention is done in succession, it is intentional, thus making up a strategy to act accordingly, as long as the organization does not suffer penalties or delegitimation (SUCHMAN, 1995).

Oliver (1991) points out that organizations do not behave passively in the face of institutional pressures and expectations, nor resign themselves to all the conditions of the institutional context. Although the author did not conduct the analysis considering the competition of multiple logics, it is possible to consider the strategic practice of circumventing rules in such an environment. Therefore, organizational practice can range from passive compliance to active resistance in response to institutional pressures, depending on the nature and context of such pressures, leading to the following possible responses: acquiescence, compromise, avoidance, confrontation, and manipulation.

Oliver's (1991) presuppositions about organizational behavior combine the types of strategic responses with characteristics of the institutional context as the causes and sources of institutional pressures. According to the author, the lower the 
perception of social legitimacy that the organization achieves by conforming to institutional rules, the greater the likelihood that organizations will resist the rules. Likewise, the lower the level of environmental uncertainty and interconnectivity between organizations, the greater the probability of organizations' resistance to institutional rules.

Organizational responses will vary according to the different types of pressure and the strength of their source. In this way, it is necessary to emphasize these different visions of the institutional pressures. Box 1 was adapted from Oliver (1991) to show how multiple logics operate, and presents the strategic responses to institutional pressures, considering only the strategies that correspond to the problem under analysis, when the companies do not seem to agree with the prescriptions.

\section{Box 1}

\section{Strategic Responses to Institutional Pressures}

\begin{tabular}{|c|c|c|}
\hline Strategies & Tactics & Description \\
\hline \multirow{3}{*}{ Avoidance } & Conceal & $\begin{array}{l}\text { Consists of disguising the non-conformity with institutional pressures and eventually } \\
\text { drawing up plans and procedures as a form of response to the requirements, to } \\
\text { conceal the non-fulfillment of the demands. }\end{array}$ \\
\hline & Buffer & $\begin{array}{l}\text { Attempts to reduce the inspection or evaluation extent performed by external } \\
\text { agents. The purpose of this tactic is to protect organizational interests, particularly } \\
\text { its autonomy, reduction of external intervention and efficiency maximization. In } \\
\text { other words, it intends to cushion or relax institutional bonds. }\end{array}$ \\
\hline & Escape & $\begin{array}{l}\text { The most dramatic way of avoiding institutional pressures. In this case, the } \\
\text { organization changes its own goals, activities or domains to avoid the need for } \\
\text { compliance. This form of strategic response occurs, for example, by altering the } \\
\text { manufactured products or the place of an installation. }\end{array}$ \\
\hline \multirow{3}{*}{ Defiance } & Dismiss & $\begin{array}{l}\text { Institutional pressures are ignored when the organization perceives low enforceability } \\
\text { by context actors, or when there is significant divergence between requirements } \\
\text { and goals, or due to the lack of understanding the consequences of conformity } \\
\text { failure. }\end{array}$ \\
\hline & Challenge & $\begin{array}{l}\text { Conditions are generated to contest or challenge the rules or requirements. This } \\
\text { tactic occurs most likely when the challenge is accompanied by the organization's } \\
\text { demonstration of rationality and probity. }\end{array}$ \\
\hline & Attack & $\begin{array}{l}\text { Presents greater intensity and aggressiveness than the Challenge tactic, with } \\
\text { an attack and denunciation of institutionalized values and sources of pressure. }\end{array}$ \\
\hline \multirow[b]{3}{*}{ Manipulation } & Coopt & $\begin{array}{l}\text { Consists of an attempt to persuade influential agents to join the organization } \\
\text { to neutralize institutional opposition and to increase organizational legitimacy. }\end{array}$ \\
\hline & Influence & $\begin{array}{l}\text { Adds to the effort to model or influence the institutional perception, values and } \\
\text { criteria. For example, lobbying for the change of institutional rules is classified } \\
\text { in this tactic. }\end{array}$ \\
\hline & Control & $\begin{array}{l}\text { Corresponds to the most active tactic, when compared to the above-mentioned } \\
\text { forms of manipulation, since it aims for domination, and not merely the influence } \\
\text { or persuasion of social actors. Control consists of the effort to establish power and } \\
\text { domination over the agents and institutional processes that put pressure on the } \\
\text { organization. This tactic occurs more frequently when institutional expectations } \\
\text { are incipient, localized, or not widely promoted. }\end{array}$ \\
\hline
\end{tabular}

Source: Adapted from Oliver (1991, p. 152).

Defiance is perceived as the most active mode of resistance to institutional pressures. This has a modest effect, since there is an established legal framework that guides the field. Dismissing the pressures will only allow the judiciary to decide with correctness. Similarly, challenging requires a rational explanation of the behavior. However, defiance buys the organization additional time and the probability of claim withdrawal, which is a useful subterfuge for those companies that must deal with many lawsuits. The last tactic has to do with adopting an attack strategy, where results can only be expected in the medium term. 
Fonseca (2003) says that avoidance involves concealing conformity. With this strategy, organizations absorb the impact of institutional pressures on certain internal areas or avoid norms and expectations. Therefore, plans and procedures can be designed without any intention of implementation. According to Fonseca (2003), objectives and practices are changed, and new markets are occupied, in which the requirements are smaller or even non-existent. Different organizational scholars see avoidance as a form of response to institutional pressures, as an organizational attempt to prevent the need for compliance (FONSECA, 2003; GREENWOOD, RAYNARD, KODEIH et al., 2011).

Manipulation as described by Oliver (1991) is related to the attempts of powerful and opportunistic organizations to coopt, influence or control the sources of pressure through institutional relations. As such, these organizations seek to change the content of institutional features or exert power over the participants in a domain. When a lawsuit is brought to justice, the possibility of manipulation is reduced because the possibility of coopting or influencing would imply illegality.

Thus, this work seeks to analyze if the health plan companies' responses to consumers' demands can be considered strategic practices, meant to avoid compliance with sector regulations. The base for this analysis is the institutional logics perspective, but we adopted Oliver's (1991) strategies as a typology that is explained in the next section.

\section{RESEARCH METHODOLOGY}

This study is a quantitative-qualitative and cross-sectional (CRESWELL, 2010) study, which analyzed 158 lawsuits filed by beneficiaries against health plan companies because of coverage denial of medical procedures. The research data covers a three-year period (2015-2017), to describe and explain the reasons for these denials in Brazil. They involve the beneficiaries' lawsuits against health plan companies, their responses, and the court's decisions as to which party was correct in relation to the regulations. The research aimed to obtain a sufficient number of coverage denials, to a saturation point when no new case was presented. In the case that a health plan company incorrectly refused to authorize a medical procedure, its allegation was analyzed according to Oliver's categories to determine which strategy was adopted (OLIVER, 1991).

The data collected from the judicial records included: (A) type of coverage denial (surgery, consultation, laboratory examination, hospitalization, medication, birth, and treatment in general,); (B) allegation offered by the company; (C) procedure cost; (D) lawsuit number; (E) name of the health plan company; (F) court sentence; and (G) the basis of the decision legal. The data were collected from the electronic archives of the State of São Paulo Court of Justice (TJ/SP), as shown in Box 2.

The different types of coverage denials, the companies' allegations for these denials, the court's decisions, and the lawsuits' financial figures were reduced to aggregated categories, and financial values were distributed in ordinal ranges. The intention was to measure the companies' response frequencies, and identify a strategic tendency that companies adopted to avoid, confront or to manipulate. 


\section{Box 2}

Example of Data from Lawsuits and their Aggregation to Analytical Categories

\begin{tabular}{|c|c|c|c|c|c|c|}
\hline $\begin{array}{c}\text { PLAN } \\
\text { denom. }\end{array}$ & $\begin{array}{c}\text { COVERAGE } \\
\text { DENIAL }\end{array}$ & $\begin{array}{l}\text { HEALTH PLAN } \\
\text { ALLEGATIONS }\end{array}$ & STRATEGY & SENTENCE & $\begin{array}{c}\text { LAW } \\
\text { REFERENCE }\end{array}$ & COST \\
\hline $\mathrm{AA}$ & Capecitabina & $\begin{array}{l}\text { Denied medica- } \\
\text { tion, stating that } \\
\text { it is not on the } \\
\text { ANS list. }\end{array}$ & Defiance & $\begin{array}{l}\text { Condemned the } \\
\text { plan to supply the } \\
\text { medicine accor- } \\
\text { ding to the medi- } \\
\text { cal prescription. }\end{array}$ & $\begin{array}{c}\text { Constitution } \\
\text { Art. 5o }\end{array}$ & $\mathrm{R} \$ 73.071,12$ \\
\hline$A B$ & $\begin{array}{l}\text { Ortopedic } \\
\text { surgery }\end{array}$ & $\begin{array}{l}\text { Denied stating } \\
\text { that the surgery } \\
\text { would be con- } \\
\text { ducted by a phy- } \\
\text { sician outside } \\
\text { the health plan's } \\
\text { defined list. }\end{array}$ & Manipulation & $\begin{array}{l}\text { Accepted the } \\
\text { demand, because } \\
\text { as an insurer } \\
\text { the company } \\
\text { is supposed to } \\
\text { accept outside } \\
\text { specialists. }\end{array}$ & $\begin{array}{c}\text { CDC and ANS } \\
\text { norms }\end{array}$ & $\mathrm{R} \$ 32.180,00$ \\
\hline
\end{tabular}

Source: Elaborated by the authors.

The first analysis of the data consisted of finding associations between the categories (LeBAR, 1977):

(A) Denial [aggregate] and (B) Allegation [aggregate]

(E) health plan company [denomination] and (B) Allegation

(E) health plan company and (A) Denial

(E) health plan company and (C) Cost [range]

A meaningful association between the categories suggests (a) that demands that were denied imply a specific allegation type; (b) that a certain health plan company tends to offer a certain kind of allegation or denial; (c) that a health plan company tends to refuse an expense in a specific cost range; or (d) that a certain type of denial is offered when the cost is within a certain range.

To specify what was purposeful and successive circumvention of prescriptions, this article considered that a high incidence of unfavorable court decisions to companies could be assumed as such an indication.

The categories are non-metric and categorical, except for the lawsuit cost, which was organized in value ranges. We used correspondence analysis (CA) for statistical treatment, since this technique offers graphic visualization of the associations found in a contingency table and the identification of the relations between the categories (GREENACRE, 2017). It also supplies useful statistics for interpreting the results (INFANTOSI, COSTA and ALMEIDA, 2014). CA is eminently descriptive in nature and, therefore, is unsuitable for hypothesis testing (HAIR, BLACK, BABIN et al., 2009). As such, this approach was selected based on the nature of the categories and the exploratory nature of the associations.

The $\beta$ test points to the possible association between the categories under study. Its value is calculated as follows:

$$
\beta=\frac{\chi^{2}-(l-1)(c-1)}{\sqrt{(l-1)(c-1)}}
$$

where $\chi^{2}$ expresses the level of independence between the categories. The higher its value, the greater the indication of independence (FARIA, 1993). I refers to the number of rows and $c$ the number of columns. If $\beta>3$, then the categories can be considered dependent (associated), to a significance level of 5\% (CZERMAINSKI, 2004; GARSON, 2006).

A second analysis classified the health companies' responses according to the strategies proposed by Oliver (1991), which resulted in the columns 'institutional strategy' in Table 1: 
(a) If the treatment prescribed by the specialist and demanded by the beneficiary is included in the ANS list or is mentioned in the contract, however the health operator denies it, the action is classified as 'defiance'.

(b) Under the same circumstances, the operator's response is unclear or when there is no effective refusal, but a deferral or lack of return to the beneficiary, this response is interpreted as 'avoidance'.

(c) Under the same circumstances, the companies' response consists of a diverse interpretation of what is established; in this case the response is seen as 'manipulation'.

The conceptual model presented in the theoretical section used the data surveyed to analyze the companies' intention in circumventing obligations using correspondence analysis. Thematic analysis (BARDIN, 2007) and Oliver's taxonomy was employed to identify the companies' responses to beneficiaries. The indication of purposeful and successive circumvention was confirmed from unfavorable court decisions to companies.

\section{RESULTS AND ANALYSIS}

\section{Institutional context}

In the context examined here, despite the private health sector's regulation, conflicts arising from the relationship between beneficiaries and private health plan companies persist and, in many cases, these disputes are resolved by the courts. According to the São Paulo Court of Justice (TJ/SP), lawsuits against health plans increased 10.6\% between 2016 and 2017 (OLIVEIRA, 2017), and across the country reached 392,000 cases (CONSELHO NACIONAL DE JUSTIÇA, 2014). The data point to the 'judicialization' of private healthcare and this suggests the successive circumvention by organizations of their responsibilities.

Data released in April 2017 by the Observatory for the Judicialization of Supplementary Health, Department of Preventive Medicine, Faculty of Medicine, at the University of São Paulo (FORMENTI, 2017) show that the growth trend continued in 2017. From January to March, there were 4,775 lawsuits filed at the court's first instance in São Paulo against health plan companies. The main complaints were strikingly similar, consisting of medical coverage denials, contracts unilateral termination by operators, and abusive increases on monthly payments.

Scheffer (2006), a professor in the Faculty of Medicine at the University of São Paulo and a member of the board of directors at the Brazilian Institute of Consumer Protection (Idec), states that the data released by the faculty show only part of the problem, since conflicts involving beneficiaries and health plan companies are spread between claims filed at the National Supplementary (private) Health Agency - ANS, lawsuits, complaints in consumer protection agencies and in companies' human resources departments, in the case of collective health business plans. With this, he concludes that there is an underreporting that underestimates the problem of private health care in Brazil, which is controlled by a few large business groups.

Based on the institutional context frame, we defined the categories and we looked for association indications between the categories (LEBAR, 1977) as explained in the methodology.

\section{Procedures and categories}

Before arriving at the final sample size, it was necessary to screen the lawsuits, because it was not possible to know a priori which cause surveyed at the TJ/SP website would satisfy the conditions being searched. The website is designed to respond to a search by cause number or a defendant's name, however, our search required a narrower search to find the causes related specifically with health plan companies (the results brought other cases) that denied medical coverage (results brought other kinds of complaints).

During this process, 672 lawsuits were reviewed to arrive at the final sample. We screened lawsuits that mentioned one of the eight big health plan companies commercialized in the state of São Paulo (ANS, 2016), and only 158 required a medical procedure. Among these 158, those that had not yet been resolved were discarded and, 80 lawsuits remained against five health plan companies. 
Lawsuits were grouped in five demand categories according to the similarity in the (III) procedures or treatments denied: (1) surgery/birth, including cardiac, orthopedic, renal surgeries, and birth; (2) consultation/examination, including physician consultations in general, laboratory tests such as blood, urine, feces, MRI and X-rays; (3) homecare/hospitalization, including intensive home care and hospitalization for different reasons; (4) treatment is a group formed by rehabilitation services, such as: physiotherapy, speech therapy, hemodialysis and occupational therapy; and (5) medicine, including medicine such as Belimumab, Capecitabine, Daclatasvir, and Lenalidomide.

Health plans companies allegations (IV) were also grouped in five categories according to similarity:

(1) 'no contractual coverage': claims in which the coverage was denied on allegations that procedures were not included in the contract;

(2) 'not on the ANS list': operators' allegations for denying coverage with the justification that they did not appear on the list of medicines/procedures/treatments/services established by ANS;

(3) 'white denial': companies did not present any justification for denials with expired deadlines, ignoring complaints made in writing by the beneficiaries, or not returning the beneficiaries' requests by telephone or e-mail;

(4) 'plan cancellation': the cancellation of the contract without any notification or knowledge from the beneficiaries was the justification for the companies' denial; and;

(5) 'grace period': companies denied coverage justified by non-compliance with the conditions established in the contract.

Demand costs (VII) were also grouped in five categories: (1) small amount (up to $R \$ 12,499),(2)$ intermediate ( $R \$ 12,500$ 24,999), (3) high ( $R \$ 25,000-37,499)$, (4) elevated ( $R \$ 37,500-50,000)$, and (5) superior (above $R \$ 50,000)$.

Among the 80 cases studied, decisions were widely favorable to beneficiaries; 74 ( $93 \%$ of the sample) cases had their demands granted, which can be explained since the right to health is defined as a social right, included in the federal constitution as a duty of the state. Two categories concentrated the majority of denials, with 44 out of 80 , surgery/birth and homecare/hospitalization. In terms of allegations from operators, 'no contractual coverage' and 'not on the ANS list' totaled 48 lawsuits (60\%).

\section{Allegations Vs Denials}

The results shown in Figure 1 indicate that medication denial (A5-MEDICA) and treatments (A4-TRATAM) are closer to the allegation - not on the ANS list (B2-ROLANS); the denial for surgery/birth (A1-CIRPAR) is directly associated with white denial (B3-NEGBRA); consultation/examination (A2-EXACON) and homecare/hospitalization (A3-HOCINT) are associated with plan cancellation (B4-CANCPL) allegations, grace period (B5-CARENC), and no contractual coverage (B1-SEMCOB).

It is possible to notice different types of responses according to the types of beneficiaries' demands. In general, surgeries and birth, which generally imply costly procedures, do not get any kind of response, supposedly in hope that the demandants may give up. When it is the case of expensive medicines, companies appeal to the regulator's norm. This study found specific strategic responses adopted by health plan companies. 
Figure 1

Correspondence Map between Allegations and Denials

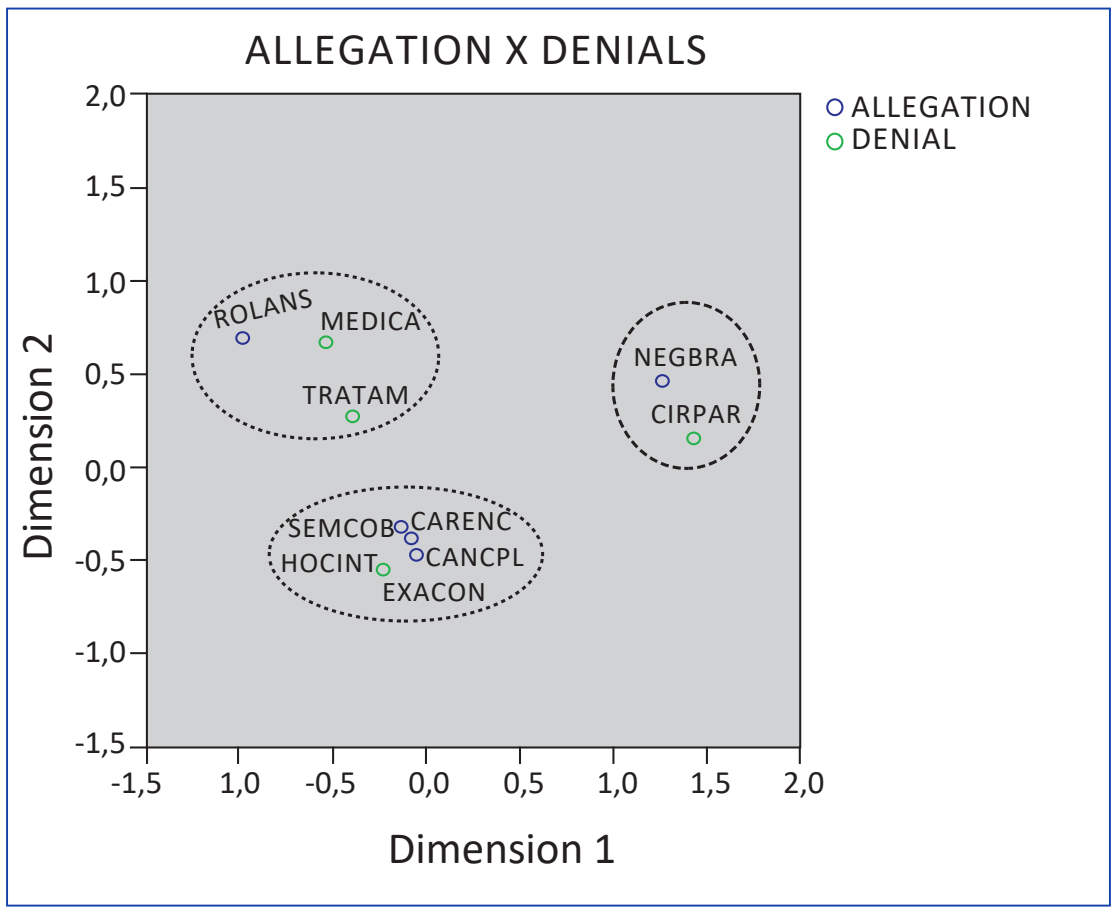

Source: Elaborated by the authors.

The value for $\beta=3,3$ indicates a significant association between Allegations and Denials.

\section{Allegations Vs Health Plan Companies}

The results shown in Figure 2 indicated the different strategies companies use in their allegations to deny medical coverage. Company AA is closer to the allegation - not on the ANS list (B2-ROLANS); company AB is associated to the allegation no contractual coverage (B1-SEMCOB); $A C$ is associated with the grace period (B5-CARENC); AD is associated with white denial (B3-NEGBRA), and AE is associated with plan cancellation (B4-CANCPL). 
Figure 2

Correspondence Map between Plans and Allegations

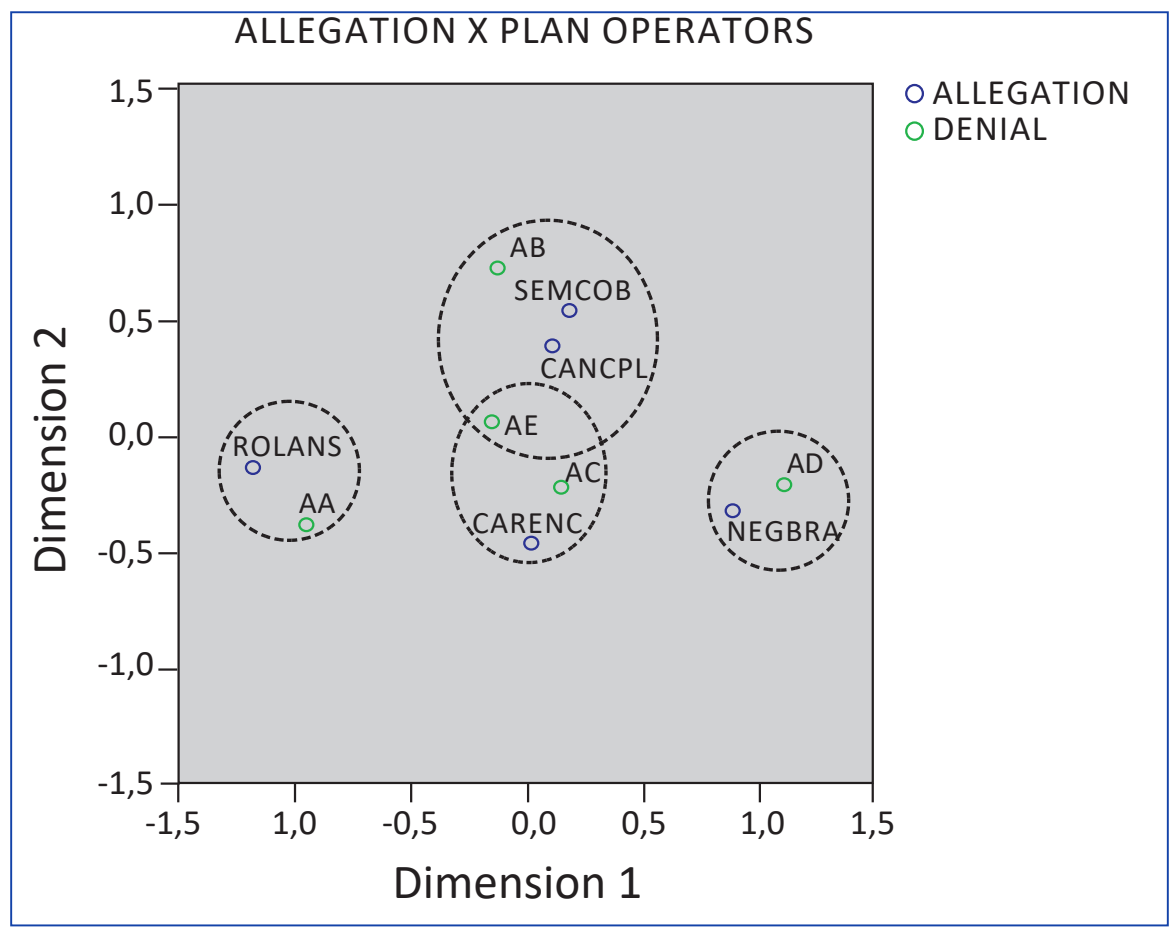

Source: Elaborated by the authors.

The value $\beta=3,1$ slightly superior to 3 , is the reference to accept a significant relation between the operators and allegations at $5 \%$.

\section{Denials Vs Health Plan Companies}

This correspondence analysis represents the categories denials and health plan companies, which is convergent with the previous analyses. Company $A D$ is closer to denying surgery/birth and consultation/examination; denials by company $A B$ are also associated with these two types; while denials by company AA are associated with treatments and medicines; and the denials by $\mathrm{AC}$ and $\mathrm{AE}$ concentrate around homecare/hospitalization.

The $\beta=2,7$ value is below but near level 3 , which does not assure a $5 \%$ significance in the association between denials and health plan companies. However, it is justifiable to maintain it, given the graphical indications of association.

\section{Costs Vs HealthPlan Companies}

The association between health plan companies and lawsuit costs that were denied indicate that company AA refused demands of small amounts - up to $R \$ 12,499$; while $A C$ refused in the range of $R \$ 25,000-37,499$, and $A D$ to the range above $R \$ 50,000$.

Since $\beta=2,4$ is inferior to 3 , it jeopardizes the association at $5 \%$ significance level. The graphical map, however, indicates some association level between the categories.

The summary of this first analysis is that each health plan company seems to have a specific strategic orientation when responding to beneficiaries demands and to the costs associated with each procedure.

\section{Institutional strategies}

The analysis of institutional strategies (OLIVER, 1991), according to the proposal in the methodology section, presented in Box 2, features the following figures: 
Table 1

Strategies Derived from Allegation

\begin{tabular}{l|c|c|c|c}
\hline \multirow{2}{*}{ Allegations Aggregated } & \multirow{2}{*}{ Frequency } & \multicolumn{3}{|c}{ Institutional Strategy } \\
\cline { 3 - 5 } & & Defiance & Avoidance & Manipulation \\
\hline No contractual coverage & 21 & 12 & - & 9 \\
\hline Not on the ANS list & 22 & 18 & - & 4 \\
\hline 'White denial' & 16 & - & 11 & 5 \\
\hline Plan cancellation & 10 & 7 & - & 3 \\
\hline Grace period & 5 & 5 & - & - \\
\hline & 74 & 42 & 11 & 21 \\
\hline
\end{tabular}

Source: Elaborated by the authors.

Table 1 was derived from the thematic analysis of the health plan companies' allegations. It shows which strategies were favored in the sample studied. Based on the premise adopted in this work that when the beneficiary gets a favorable sentence, this indicates that the company has chosen a strategy to try to circumvent the regulation. As such, the cases of favorable sentencing to the company were dropped.

It is noticeable that the majority of the lawsuits are due to the health plan companies' denials of consumers' rights by defying or manipulating the regulations. Companies may assess that, given the number of complaints, from an economic point of view, it is more important to dismiss a portion of such demands, guessing that an important number among them will not be carried ahead by the beneficiaries, and that this will not impair the company's legitimacy. Manipulation, which involves reinterpreting the regulation, is a less favored strategy, and avoidance without any attempt to offer an explanation is even less favored, which is surprising, since the cause is invariably lost when an appeal is offered.

\section{Discussion}

The results of this research show the intentional circumvention of regulations, where companies use specific strategies to handle demands. This research has shown that $90 \%$ of the lawsuits dealing with one issue, medical procedures coverage (74 out of 82), were in favor of the beneficiaries. Therefore, it is possible to assume that health plan companies purposefully and repeatedly circumvent institutional prescriptions.

This is contrary to institutional studies on prescriptions circumvention by organizations, where it is assumed that institutional participants may need to evade such guidelines, but not in succession, indicating strategic design (MEYER and ROWAN, 1991; REAY and HININGS, 2009; GOODRICK and REAY, 2011).

More interestingly, the findings indicate that the defiance strategy was the most used (57\%), while the avoidance strategy was the least used (15\%). Manipulation together with avoidance might be expected to be used much more than defiance, because the latter implies risks of losing legitimacy (OLIVER, 1991). Considering that non-compliance with institutional prescriptions implies risks of receiving sanctions, penalties, or facing delegitimation in the context (SUCHMAN, 1995), it is interesting to explore the reasons that encourage these companies to deny beneficiaries' claims and demands.

It can be inferred that, under a market logic, health plan companies have considered that of the high amount of claims/ demands they receive, only a small percentage will bring their claims to the courts, and thus the savings with the rest represents a financial gain in operational terms. The trial at a court of the first instance is only the first step in a long process that allows several appeals, allowing for the postponement of the compliance with a demand (WAMBIER, DIDIER, TALAMINI, et al., 2015). The company may primarily want to privilege its economic performance, and finds support in the public logic pressure, which carried out by means of bureaucratic instruments, contributes to this postponement and may result in the beneficiary desisting. This process contains the intervention of other logics, which may influence the companies' decisions, as is the case of a professional medical logic from physicians and providers, such as hospitals and laboratories. 
Another possible reason for acting in such manner is probably because the legitimacy loss is small, as medical demands are sporadic in the life of most individuals and not a continual concern.

The regulation of the supplementary or private health sector in Brazil began after more than three decades of operation without any government control. However, by regulating the supplementary health sector, the government opted for a model that would strongly regulate the product offered, with innovative measures such as the prohibition of risk selection and the unilateral disruption of contracts (OCKÉ-REIS, 2005; PILOTTO, 2016). With the adoption of the CDC and the creation of ANS, consumers now have additional protection. However, these events proved insufficient to successfully regulate the relations between consumers/beneficiaries and companies.

The main organizations responsible for implementing the CDC, the Procon (Consumer Protection Foundation, a public agency), are not authorized to develop rules for the sector, and are restricted to the imposition of fines, which the companies can almost always appeal. The easiest and shortest option for consumer claims is to appeal to the courts, because when facing a health risk, the consumer is unlikely to expect an intermediation that takes a long time.

\section{CONCLUSION}

Despite the wide dissemination and popularization of private health plans, access to quality health remains a problem in Brazil. In recent years, supplementary health care companies have been the target of investigations and inspections resulting from abusive payment increases, poor performance or denials of health care services. Often these same companies lead the complaints rankings at the state Procons for these reasons.

Health plan beneficiaries have different channels to which they can look for a solution. They can rely on Procon, on ANS, on consumer defense organizations to file complaints against health plan companies, seeking a solution to the conflict at the administrative level and avoiding its 'judicialization'. However, due to the urgency that these cases can imply, the beneficiaries have addressed the courts to the detriment of the administrative channels, mainly in regard to the refusal by the health plans to cover medical procedures, since the courts immediately assure the coverage sought by means of a precautionary measure, while leaving the examination of the requests' merit for later.

This has raised the issue of repeated circumvention in relation to institutional prescriptions. This article reviewed the institutional literature in relation to circumvention, and noticed that mostly it had to do with sporadic events. However, the specific cases surveyed in the lawsuits point to the recurrent presence of actions characteristically associated with circumvention strategies. When considering the absolute majority of verdicts favorable to the beneficiaries, it is possible to see the use of strategic routine protocols by the companies.

The analysis of the sample surveyed, using the correspondence maps for the dimensions studied and the thematic analysis of the institutional strategies, allow to see that companies adopt specific strategies for the different demands presented by consumers. Therefore, it is possible to infer that each company is more associated with a certain kind of claim, denial, and cost. This suggests that each company privileges a type of treatment to the complaints received at the courts. And, instead of adopting strategies to disguise its non-compliance, the study showed that companies were not afraid of confronting the institutional directives, while using manipulation and avoidance strategies.

In addition, the examination of the court cases has shown the tendency of health plan companies to challenge the ANS norms. Such procedures suggest that not complying with the institutional indications is better, due to the lack of apprehension that could result in harm to the companies. An organization may diverge substantially from social norms and still retain its legitimacy, because this goes unnoticed or because other actors do not consider the relevant wrongdoing (SUCHMAN, 1995).

The results answer the research question, since the strategies of defiance, manipulation and avoidance are evident in the allegations presented by the health plan companies to the beneficiaries and the high percentage of favorable decisions to the latter, as well as the fact that the legal grounds pointed out by the judges in the rulings demonstrate flagrant noncompliance 
with the laws that regulate the provision of private health services and contracts signed between companies and the beneficiaries of health plans.

This research contributes to the literature with the following relevant implications, one of a theoretical, a methodological, and a managerial nature: (1) repeated circumvention of institutional parameters may be the result of deliberate organizational decision, with the example of health care companies that assess the best strategy to adopt in each situation, despite the existence of a regulation; (2) the use of graphical association techniques, such as multidimensional scaling, offers a relevant alternative in the identification of organizations' practices vis-à-vis the practices of other context actors, that in the case examined were mainly the beneficiaries; (3) the circumvention and confrontational practices call for the revision of public policies and consumer protection against organizations actions.

This study was restricted to investigating only lawsuits filed by beneficiaries of private health insurance plans against coverage denial by the companies, which excluded the analysis of the causes for undue payment increases, defaults, or unilateral termination of contracts. Another restriction was the scope of the research, which did not include the study of cases filed in the administrative sphere. A suggestion for future studies would be to analyze coverage denials more broadly and in different social contexts, to analyze whether there is a relationship between coverage refusals and the age groups of the beneficiaries, especially in those over 60 years, as this age group has more beneficiaries attached to health plans prior to Law 9656/98. 


\section{REFERENCES}

AGÊNCIA NACIONAL DE SAÚDE SUPLEMENTAR - ANS. Caderno de Informações da Saúde Suplementar: beneficiários, operadoras e planos. Rio de Janeiro: ANS, 2016.

ALBUQUERQUE FILHO, B. et al. Práticas organizacionais e estrutura de relações no campo do desenvolvimento metropolitano. RACRevista de Administração Contemporânea, v. 13, n. 4, p. 626646, 2009.

BARDIN, L. Análise de conteúdo. 3. ed. Lisboa: Edições, 70, 2007.

BATTILANA, J.; LECA, B.; BOXENBAUM, E. How actors change institutions: Towards a theory of institutional entrepreneurship, Academy of Management Annals, v. 3. p. 65-107, 2009.

BATTILANA, J.; DORADO, S. Building sustainable hybrid organizations: The case of commercial microfinance organizations, Academy of Management Journal, v. 6, p. 1419-1440, 2010.

BERGER, P. L.; LUCKMANN, T. The social construction of reality: A treatise in the sociology of knowledge. Penguin Social Sciences, 1991.

BLACK, J. Critical reflections on regulation. In: RAFUSE, E. S. (Ed). Crime and Regulation. London: Routledge, 2017. p. 15-49.

BOXENBAUM, E.; JONSSON, S. Isomorphism, diffusion and decoupling. In: GREENWOOD, R. et al. (Eds.). The Sage handbook of organizational institutionalism. Thousand Oaks: SAGE, 2008. p. 78-98.

CONSELHO NACIONAL DE JUSTIÇA - CNJ. Resolução CNJ no. 107. Available at: <http://www.cnj.jus.br/images/programas/ forumdasaude/demandasnostribunais.forumSaude.pdf $>$. Accessed on: Nov. 10, 2017.

CRESWELL, J. W. Projeto de pesquisa: métodos qualitativo, quantitativo e misto. Porto Alegre: Artmed, 2010.

CZERMAINSKI, A. B. Análise de correspondência. Available at: <http:// ce.esalq.usp.br/tadeu/anabeatriz.pdf>. Accessed on: Nov. 10, 2017.

DACIN, M. T.; GOODSTEIN, J.; SCOTT, W. R. Institutional theory and institutional change: Introduction to the special research forum. Academy of Management Journal, v. 45, n. 1, p. 45-56, 2002.

DURAND, R.; KREMP, P. A. Classical deviation: Organizational and individual status as antecedents of conformity. Academy of Management Journal, v. 59, n. 1, p. 65-89, 2016.

FARIA, R. T. de. Tratamento de dados multivariados através de análise de correspondência em rochas carbonáticas. 1993. [151] f. Thesis (Master Degree in Reservoir Geoengineering) - Universidade Estadual de Campinas, Instituto de Geociências, Campinas, 1993.

FLIGSTEIN, N.; MCADAM, D. A theory of fields. Oxford: Oxford University Press, 2012.

FONSECA, V. S. A Abordagem Institucional nos Estudos Organizacionais: Bases Conceituais e Desenvolvimentos Contemporâneos. In: VIEIRA, M. M. F.; CARVALHO, C. A. (Eds.). Organizações, Instituições e Poder no Brasil. Rio de Janeiro: FGV, 2003.

FORMENTI, L. Ações contra planos de saúde disparam em São Paulo; em 2017, são 117 por dia. Estadão, São Paulo, 30 abr. 2017. Available at: <http://saude.estadao.com.br/noticias/geral,acoes-contra- planos-de-saude-disparam-em-sao-paulo-em-2017-sao-117-por-dia, 70001757754>. Accessed on: Nov. 10, 2017.

FRIEDLAND, R.; ALFORD, R. R. Bringing society back in: Symbols, practices and institutional contradictions. In: POWELL, W.; DIMAGGIO, $P$. (Eds.). The new institutionalism in organizational analysis. Chicago: University of Chicago Press, 1991.

GARSON, G. D. Correspondence analysis. Available at: <http://www2. chass.ncsu.edu/garson/pa765/correspondence.htm>. Accessed on: Nov. 10, 2017.

GOODRICK, E.; REAY, T. Constellations of Institutional Logics: changes in the professional work of pharmacists. Work and Occupations, v. 38, n. 3, p. 372-416, 2011.

GREENACRE, M. Correspondence analysis in practice. Boca Raton: CRC press, 2017.

GREENWOOD, R. et al. Institutional complexity and organizational responses, Academy of Management Annals, v. 5 n. 1, p. 317-371, 2011.

GREVE, H. R.; MAN ZHANG, C. Institutional logics and power sources: merger and acquisition decisions. Academy of Management Journal, v. 60, n. 2, p. 671-694, 2017.

HAIR, J. F. et al. Análise multivariada de dados. Porto Alegre: Bookman, 2009.

HARDY, C.; MAGUIRE, S. Institutional entrepreneurship. In: GREENWOOD, R. et al. (Eds.). The SAGE handbook of organizational institutionalism. Thousand Oaks: SAGE, 2008. p. 198-217.

INFANTOSI, A. F. C.; COSTA, J. C. G. D.; ALMEIDA, R. M. V. R. Análise de correspondência: bases teóricas na interpretação de dados categóricos em ciências da saúde. Cadernos de Saúde Pública, v. 30, n. 3, p. 473-486, 2014.

LAMPREA, E. The Judicialization of Health Care: a global south perspective. Annual Review of Law and Social Science, v. 13, p. 431-449, 2017.

LAWRENCE, T. B.; SUDDABY, R.; LECA, B. Institutional work: actors and agency in institutional studies of organizations. Cambridge: Cambridge University Press, 2009.

LAWRENCE, T. B.; SUDDABY, R.; LECA, B. Institutional work: Refocusing institutional studies of organization. Journal of Management Inquiry, v. 20, p. 52-58, 2011.

LEBAR, F. M. Insular Southeast Asia: ethnographic studies. New Haven: Human Relations Area Files, 1977. v. 1.

LEBLEBICI, H.; SALANCIK, G.; COPAY, A.; KING, T. Institutional change and the transformation of interorganizational fields: an organizational history of the U.S. radio broadcasting industry. Administrative Science Quarterly, v. 36, p. 333-363, 1991.

LEE, M. D. P.; LOUNSBURY, M. Filtering institutional logics: community logic variation and differential responses to the institutional complexity of toxic waste. Organization Science, v. 26, n. 3, p. 847-866, 2015.

MALTA, D. C. et al. Duas faces da mesma moeda: microrregulação e modelos assistenciais na saúde suplementar. Rio de Janeiro: ANS/ Ministério da Saúde, 2005. v. 1. 
MEYER, J. W.; ROWAN, B. Institutionalized organizations: formal structure as myth and ceremony. In: POWELL, W. W.; DIMAGGIO, P. J. (Eds.). The new institutionalism in organizational analysis. Chicago: University of Chicago Press, 1991.

MICELOTTA, E.; LOUNSBURY, M.; GREENWOOD, R. Pathways of institutional change: An integrative review and research agenda. Journal of Management, v. 43, n. 6, p. 1885-1910, 2017. NEE, V. Sources of the new institutionalism. In: BRINTON, M. C.; NEE, V. (Eds.) The new institutionalism in sociology. New York: Russell Sage Foundation, 1998.

OCKÉ-REIS, C. O. Challenges in the regulation of Brazilian private health insurance. Public Finance and Management, v. 5, n. 4 , p. 597-624, 2005.

OLIVER, C. Strategic responses to institutional processes. Academy of Management Review, v. 16, n. 1, p. 145-179, 1991.

OLIVEIRA, C. Aumenta número de ações contra os planos de saúde na Justiça de São Paulo. Rede Brasil Atual, 13 out. 2017. São Paulo. Available at: <http://www.redebrasilatual.com.br/saude/2017/10/ aumenta-numero-de-acoes-contra-os-planos-de-saude-na-justicapaulista>. Accessed on: Nov. 10, 2017.

PACHE, A. C.; SANTOS, F. When worlds collide: the internal dynamics of organizational responses to conflicting institutional demands. Academy of Management Review, v. 35, n. 3, p. 455-476, 2010.

PILOTTO, L. M. Os planos privados de saúde no Brasil e sua influência no uso de serviços de saúde: análise dos dados da PNAD 1998, 2003, 2008 e da PNS 2013. 2016. 113 f. Thesis (Doctor Degree in Oral Health Collective) - Universidade Federal do Rio Grande do Sul, Faculdade de Odontologia, Porto Alegre, 2016. Available at: <http://www. lume.ufrgs.br/handle/10183/148219>. Accessed on: Nov. 10, 2017.

RAO, H.; MONIN, P.; DURAND, R. Institutional change in Toque Ville: Nouvelle cuisine as an identity movement in French gastronomy. American Journal of Sociology, v. 108, p. 795-843, 2003.

REAY, T.; HININGS, C. R. Managing the Rivalry of Competing Institutional Logics. Organization Studies, v. 30, n. 6, p. 629-652, 2009.
SCHEFFER, M. Os planos de saúde nos tribunais: uma análise das ações judiciais movidas por clientes de planos de saúde, relacionadas à negação de coberturas assistenciais no Estado de São Paulo. 2006. Thesis (Master Degree in Sciences) - Universidade de São Paulo, São Paulo, 2006. Available at: <http://www.unimedfesp.coop.br/SITES/29/ imagens/7EZ32_MarioScheffer.PDF>. Accessed on: Nov. 10, 2017.

SCHNEIBERG, M.; LOUNSBURY, M. Social Movements and Institutional Analysis. In: GREENWOOD, R. et al. (Eds.). The SAGE handbook of organizational institutionalism. Thousand Oaks: SAGE, 2008. p. 650-72.

SCOTT, W. R. Institutions and organizations. 3. ed. London: SAGE, 2008.

SMETS, M.; MORRIS, T. I. M.; GREENWOOD, R. From practice to field: a multilevel model of practice-driven institutional change. Academy of Management Journal, v. 55, n. 4, p. 877-904, 2012.

SPERANDIO, L. Consequências do intervencionismo no mercado de saúde suplementar brasileiro. MISES: Interdisciplinary Journal of Philosophy, Law and Economics, v. 1, p. 125-136, 2017.

SUCHMAN, M. C. Managing legitimacy: strategic and institutional approaches. Academy of Management Review, v. 20, n. 3, p. 571610, 1995.

THORNTON, P. H.; OCASIO, W.; LOUNSBURY, M. The institutional logics perspective. A new approach to culture, structure and process. Oxford: Oxford University Press, 2012.

THORNTON, P. H.; OCASIO, W.; LOUNSBURY, M. The institutional logics perspective. In: SCOTT, R. A.; KOSSLYN, S. M. (Eds.). Emerging Trends in the Social and Behavioral Sciences. New Jersey: Wiley, 2015.

TRACEY, P.; PHILLIPS, N.; JARVIS, O. Bridging institutional entrepreneurship and the creation of new organizational forms: a multilevel model. Organization Science, v. 22 n. 1, p. 60-80, 2011.

WAMBIER, T. A. A. et al. Breves comentários ao novo Código de Processo Civil. São Paulo: Revista dos Tribunais, 2015.

WANG, D. W. et al. Os impactos da judicialização da saúde no município de São Paulo: gasto público e organização federativa. Revista de Administração Pública, Rio de Janeiro, v. 48, n. 5, p. 1191-1206, 2014. 
PhD in Administration from Fundação Getulio Vargas (FGV EAESP); Professor of the Graduate Program in Administration at the Universidade Paulista (UNIP), São Paulo - SP, Brazil. E-mail: arnaldoryn@gmail.com

Paulo C. Duarte de Oliveira

ORCID: https://orcid.org/0000-0001-7549-3231

Masters in Administration from the Universidade Paulista (UNIP); Professor of the Faculty of Administration of Universidade Paulista (UNIP), São Paulo SP, Brazil. E-mail: paulo_c_duarte@hotmail.com

\section{Renato Telles}

ORCID: https://orcid.org/0000-0002-1123-668X

PhD in Business Administration from the Faculty of Economics, Administration and Accounting of the University of São Paulo (FEA-USP); Professor at the Postgraduate Program in Administration of the Paulista University (UNIP), São Paulo - SP, Brazil. E-mail: rtelles1@gmail.com

\section{Mayla C. Costa}

ORCID: https://orcid.org/0000-0002-2909-3103

PhD in Administration from Universidade Positivo (UP); Professor at the Accounting Program of the Federal University of Paraná (UFPR), Curitiba - PR, Brazil. E-mail: mayla.c.costa@gmail.com 